\title{
Theological Reflections on Two Problems Associated with the Concepts of Ideology and Discourse
}

\author{
Kayhan Ali Özaykal
}

\begin{abstract}
Ideology and Discourse represent concepts used in studies of society to understand how political order and structure is formed and maintained. The two concepts, however, are based on epistemological and metaphysical foundations antithetical to Islamic creed. It is the aim of this paper to survey these conflicts and assess how radical they are. In this context, the formulations of the concept of ideology proposed by Marx, and to a lesser extent, Althusser and Žižek, will be studied alongside the concept of discourse as framed by Foucault. The two main issues identified for discussion are truth and the human subject. This paper concludes that the philosophical framework for truth utilised by ideology and discourse is problematic not just theologically but also theoretically and must be clearly limited in its range of application. Similarly, the individual must be approached as a subject independent of ideology and discourse, again in support of Islamic teaching, if it is to be made a theoretically coherent unit of analysis.
\end{abstract}

Keywords: Sociology, Ideology, Discourse, Islamic thought, Foucault, Marx.

Öz: İdeoloji ve söylem, siyasi düzenin ve yapının nasıl kurulduğunu ve sürdürüldüğünü anlamak için toplum çalışmalarında kullanılan kavramlardandır. Ancak bu iki kavram, İslam inanç esaslarıyla çelişen epistemolojik ve metafizik temellere dayanır. Bu makale, bu uyuşmazlıkları araştırmayı ve bunların ne derecede temel olduğunu değerlendirmeyi hedeflemektedir. Bu bağlamda Marx ve kısmen Althusser ve Žižek tarafından önerilen ideoloji kavramının formülasyonları, Foucault'nun şekillendirdiği söylem kavramıyla birlikte ele alınacaktır. Tartışma için belirlenen iki ana konu, hakikat ve bireydir. Bu çalışma, ideoloji ve söylemin hakikat için kullandığı felsefi çerçevenin yalnızca teolojik açıdan değil, aynı zamanda teorik açıdan da problemli olduğunu ve uygulama sahasının açıkça sınırlandırılması gerektiğini savunmaktadır. Benzer şekilde, eğer birey kavramının daha tutarlı bir analiz birimi haline gelmesi isteniyorsa, İslami öğretiyi destek verecek şekilde, bu konuya ideoloji ve söylemden bağımsız olarak yaklaşılması gerekecektir.

Anahtar kelimeler: Sosyoloji, İdeoloji, Söylem, İslam Düşüncesi, Foucault, Marx. 


\section{Introduction}

The concepts of ideology and discourse, which have become popular tools in sociological studies, have certain specific theoretical suppositions that are neutral neither in their epistemological nor metaphysical views. Ideology is a term utilised in different ways by different thinkers, and this study attends primarily to Marx, and to a much lesser extent Althusser and Žižek. Discourse, presents less difficulty because it has meanings and applications that are primarily associated with Michel Foucault. The concepts belong to the history of secular developments in Western thought specifically, which leads one to ask how well these concepts are suited to Islamic religious teachings. Thus, this article concentrates on the philosophical implications of these concepts rather than their sociological application. I seek to identify and clarify theological problems that the concepts pose and attempt to find justification for their rejection not simply on the basis of their incompatibility with Islamic teaching but also due to internal problems that the concepts face, which in turn indirectly provide support for the correctness of those Islamic teachings. That is to say, there is a correspondence of the internal problems of these concepts with resolutions in Islamic thought. There are two main subjects under which the problems fall, namely the truth and the human subject, which shall be each treated separately below.

\section{Theoretical Foundations: Truth and Science}

In the case of mediaeval Christian Europe, the decline in the credibility of religious belief, due in part to the Church's fateful involvement with outdated scientific theories, lead to philosophical repercussions regarding the source of true knowledge with subsequent replacements of these specific theological sources with new and secular ones (see Norgaard, 1994; DeJean, 1997). The arrival of new sciences such as sociology along with new philosophies replaced the old sources of meaning that were previously occupied by theology and theologically imbued philosophies (Keller, 1950, p. 235). Hence the search for truth became satisfied by alternative explanations that tended to assume the invalidity of religious sources of knowledge (Başdemir, 2005). The enlightenment saw the introduction of replacements rather than complements to religious thought across almost every sphere of inquiry. Scottish and German thinkers, unlike their French counterparts, did attempt to maintain room for God, but often only with deist theologies, leaving the explanation of worldly events to investigation based almost entirely on secular suppositions. Comte identified four basic classifications of natural phenomena: astronomical, physical, chemical, and physiological. In addition to these he introduced sociology, 
as a science that heralded the completion of human knowledge. He wrote, "the philosophical system of the moderns will be in fact complete, as there will be no phenomenon which does not naturally enter into some one of the five categories" (Comte, 1853, p. 33).

The Islamic world, however, did not experience the same theological crisis because Islamic creed remained sustainably independent of passing intellectual trends and scientific discovery. As a result, the new sciences did not arrive with concepts to supplant the intellectual authority of religious doctrine. Thus the main reference for explaining the truth of the world, the explanation or interpretation of events in terms of the grand scheme of things, remained theological, though without there ever being a necessary prevention of scientific investigations to explain natural phenomena. In addition, Islamic doctrine came with Islamic law, and rules on how people should behave and hence how a society should be run. And with the continuing authority and validity of Islamic creed, there was no need to change this massive extension, which shaped society in line with transcendent truth. No doubt, fiqh had to advance with the times, in relation to new technologies, customs, and unprecedented circumstances that affect human life, law and society as a whole, but its fundamental validity remained untouched. Whereas, the toppling of Christian theology, the discipline that constituted the central substance of religious intellectual endeavour and identity, left open a vacuum in European thought. It is very much on the back of this historical context that sociology, and hence, the concepts of ideology and later discourse arrived to explain social and political life.

The term ideology, first coined by Destutt de Tracy, initially referred to the "science of ideas," an enterprise concerned with the role of the senses in the formation of ideas. However, this meaning was more or less overshadowed by Napoleon's scathing attack upon this school of work, because of which the term became associated with the placement of ideal aims ahead of more immediate material interests. Thereafter the term remained unutilised by critical thought, headed as it was by French positivism and German idealism. Both were concerned with the critique of religion. The connection between mental distortions and the historical development of society was left to Karl Marx. He subsumed social illusions, not only religious, under the term ideology as a concept held in relation to the history of society and social contradictions. As Larrain states, "with Marx the concept of ideology came of age" (1979, p. 34).

Eagleton distinguishes four different uses of the term ideology in Marx's work. Firstly, in The German Ideology (1845), it denotes an imaginary resolution of real contradictions that blinds men and women to the harsh actuality of their social 
condition. Secondly, in the same work, ideology represents those ideas that directly express the material interests of the dominant social class, and are useful in promoting its rule. Thirdly, in the Preface to the Contribution to a Critique of Political Economy (1859) ideology signifies all the conceptual forms in which the class struggle as a whole is fought out, including, therefore, the valid conclusions of politically revolutionary forces. Finally, Marx writes in Capital (1867) that ideology denotes the mind reflecting a real inversion of material relations (see also, Pilling, 2009, pp. 107-108). Eagleton cites some advantages to this version, for now ideology has a clear basis in reality and is not an ungrounded fiction. Yet the negative connotation still applies for there is a concealment of the falsity or rather incorrectness of reality (Eagleton, 1991, pp. 77-87).

Larrain places the different conceptions of ideology within the context of two basic polarities found in Marx's work: base-superstructure and practice-consciousness. These lead to different ideas of how ideology is produced and what features it has. The first makes ideology "directly determined by the economic structure," the second a "free and conscious product of a subject". This dissimilarity has led to many interpretive efforts at integration (Larrian, 1979, pp. 63-67). The first conception stems from Marx's assessment of ideology as a "reflex" to material life and his critique of Hegel and the Young Hegelians, who failed to correctly connect thought to historical society. While they think they have gone from "heaven to earth", Marx writes, in fact they have gone from "earth to heaven" (Marx \& Engels, 1976, p. 47). The second conception, however, can also be seen to stem from the first three definitions listed above, where space is given for individual human contributions to the thoughts governing society. For our purposes here, one thing is crucial. With Marx, ideology is concerned with truth-apt descriptions of society's economic and political relations.

Foucault's concept of discourse is even more radically comprehensive of human thought than Marx's concept of ideology. It encompasses practically all our knowledge, not just the ideas of ruling class philosophers or social scientists. Discourse functions as "a 'regime' of truth" that is "not merely ideological or superstructural" (Foucault, 1980, p. 133). "We shall call discourse a group of statements in so far as they belong to the same discursive formation" (Foucault, 1972, p. 117). In this way, Foucault thus refers, on the one hand, to statements anterior to class conflict, but on the other hand, not to just any type of speech acts. Rather he refers to statements (énoncé) that Dreyfus and Rabinow label as "serious", that is to say, 
"what experts say when they are speaking as experts" (1983, p. xxiv). ${ }^{1}$ They do not have to be spoken; a map may be seen as a statement. Significantly, however, Foucault brackets firstly the truth of each and every serious truth claim and secondly also its intelligibility. ${ }^{2}$ He thus moves beyond an analysis of actual experience that grounds the validity of speech acts in perception. Both reference and meaning are treated as mere phenomena in order to locate what is serious and meaningful to an age without its being so to the phenomenologist (Dreyfus \& Rabinow, 1983, pp. 50-52). This type of analysis creates a "pure description of discursive events." It is an historical analysis about a statements' mode of existence. British philosopher Collingwood argued that metaphysics is an historical study, a search for the particular "absolute propositions" of any certain time and place (Collingwood, 1983). On this basis, then, Foucault is akin to a metaphysician who sought the "historical... conditions of possibility" in Europe since the Renaissance (Dreyfus \& Rabinow, 1983, p. 15). The discourse of each period is produced on the basis of the particular épistème that held sway at the time. In The Order of Things, Foucault attempted to discover on what historical a priori knowledge and theory became achievable, and exposed at the same time their discontinuity, looking at the sciences closest to the human being in concern: linguistics, biology, and economics (Foucault, 2002).

Later, Foucault's reading of Nietzsche inspired the creation of a genealogical approach that paid more attention to non-discursive practices, and épistème was replaced by the notion dispositif. ${ }^{3}$ Whilst retaining some of the techniques of excavation employed previously, genealogy allows study and interpretation pertain-

1 Statements are neither propositions nor utterances, since in the first case the same sentence with the same meaning can be different statements depending on its truth conditions, and in the second case, several different utterances can be repetitions of one identical statement. However, Foucault's term fails to explicitly distinguish the statements he was interested in from everyday speech acts that are understood in a local context against a shared background of non-discursive practices. Rather, Foucault's statements pass some kind of institutional test thereby constituting a relatively autonomous realm without the need to refer to the everyday context of the statements utterance. These serious speech-acts instead occur in a context where truth and falsity have serious social consequences. This difference is the reason cited by Dreyfus and Rabinow for their preference of the term "serious speech-acts" (1983, pp. 45-48).

2 In so doing Foucault can recognise serious speech-acts only because people can be seen as having taken them seriously themselves, by selecting, defending, criticising, commenting etc. (Dreyfus \& Rabinow, 1983, p. 52). So if everyone went insane and took something that was neither true nor even comprehensible seriously, Foucault too would take it seriously, at least in his work. Hence listening to the voice of the "Other",

3 The usual translation of this term is "apparatus" since this conveys Foucault's pragmatic concern that concepts be used as tools to aid in analysis, not as ends in themselves. Dreyfus and Rabinow, however, propose "grid of intelligibility" because it not only highlights the method of the effective historian but also the structure of the cultural practices he is examining. Foucault is trying to isolate and establish the exact kind of intelligibility that practices have (1983, pp. 120-121). 
ing to the significance of the so-called objective social sciences for our society. The interpretation, or rather diagnosis, of our current situation does not concern any fixed or absolute primary. It is considered that underneath everything is already interpretation. Thus genealogy opposes itself to traditional historical method, rejecting fixed essences, underlying laws, and metaphysical finalities. The basic supposition to the genealogical approach is that falsity and, its opposite, truth, are also historical relations. For Foucault, truth "is to be understood as a system of ordered procedures for the production, regulation, distribution, circulation and operation of statements" (1980d, p. 133).

So how do these concepts apply to Islam? The first distinction that must be pointed out is between the concepts of ideology and discourse and those things that we term ideology and discourse, just like there is the concept of a science and then there is the science itself. This is for two reasons. First, in relating something to one of these concepts, we must know whether one is specifying an equivalent concept with a similar investigative role or a subject that falls under that investigation. Certainly, in Islamic scholarship there have been identifications of ideological phenomena, like Ibn Khaldun's concept of asabiyya, translated as social solidarity or group spirit (Ibn Haldun, 2007, p. 95; Lacoste, 2002, pp. 178-186). But such a comparison is not our aim. Second, where knowledge itself is in question, one must be able to distinguish one's own concepts, which are supposed to possess authority, from the objects of study that one seeks to explain, whether positively or critically. Naturally, maintaining the distinction is not always easy (we shall return to this issue below). Thus, when we apply these concepts to Islam, we are talking about Islamic ideologies or Islam itself as an ideology, Islamic discourses or Islam as discourse.

With Marx and Foucault, Islam itself would fall within the sphere of the respective concepts in question as a subject of study. Marx famously described religion as the opium of the people (2009, p. 131) and regarded it as an ideological tool for the continued exploitation and control of the working class (Plamenatz, 1977, p. 337). But then there is the more positive concept of ideology Marx has, noted above. In The German Ideology, ideology refers to all the conceptual forms in which the class struggle as a whole is fought out. This positive meaning broadens the term to include the (correct) proletariat outlook as well as the (falsifying) bourgeoisie outlook, and thus encompasses also the valid consciousness of the politically revolutionary forces. So we have two notions, which one might think could unproblematically be applied to religion too. But this is not so. For Marx's framework reduces the source of ideology to a single totalising contradiction in society. Unless we wish 
to explain revelation simply in terms of arriving to resolve this contradiction, then there is a problem. Of course, one might allow for a communist dimension to revelation without reducing it to that dimension, but a corresponding metaphysics would be needed, and this, as we shall see, is lacking in Marx.

Thus, while the content of a given ideology may or may not be correct or truth apt (this is not a debate of concern here), the concept as it stands must be amended to become doctrinally acceptable to Islam because of the potential subsumption of religion to secular sources. By contrast, a fair survey of the early development of Islamic society, which must go hand in hand with study of the development of the Islamic sciences, will reveal that the Muslim intellectual and scholarly endeavour was geared heavily toward maintaining the integrity of a message and teachings whose source was considered sacred (El Shamsy, 2008). The Islamic science with the most central influence on the character of Muslim societies has been that of Islamic Jurisprudence, or fiqh. The root basis of Islamic law is the Quran and the sayings and practices (sunnah) of the Prophet Muhammad. The rules given directly therein constitute the shariah (lit. path), which includes creed and morality, whereas fiqh (lit. deep understanding) denotes the body of law that derives from the intellectual labour Muslim scholars carried out in light of the shariah and other evidence. The two do overlap in that fiqh includes the judgments of the scholars when they are true, like the shariah, but only fiqh can include errors resulting from their reasoning, as well as judgments made according to the individual time and place (Askar, 1423/2003, pp. 18-20) (Qardawi, 1990, pp. 21-23). As Erdoğan notes, there is great consensus among the ulama in fiqh despite the application of interpretation (2003, p. 175). This labour is carried out according to methods and principles whose specifics and validity are discussed in another science, namely, usul al-fiqh (the principles of Islamic jurisprudence). This science includes areas that overlap with issues in ethics, metaethics, philosophy of law, epistemology and other branches of philosophy, as it explicates the foundations for fiqh itself. The basic task that has remained the same over centuries across different periods of history is to correctly understand and apply the revealed teachings. Therefore, to attempt any explanation of this truth in terms of economic forces during that period of preservation does an injustice to the intention and success of these scholars. More importantly, economic explanations for the arrival of the message itself prejudicially leave no possibility of its being correct, radically conflicting with Islamic belief.

As for discourse, if Islam were such an object, it would again come under a secular explanation, but not directly. Rather, Foucault approaches religion in terms of its social effects. Thus, for example, his treatment of monasticism comes as a study 
of education and penal control (Carrette, 2000, p. 118). Indeed, Foucault isolates specific sites of learning in order to isolate the relations of power-knowledge. He concentrates on the human sciences, since they produce discourses about society, human beings, and language that all emanate from the practice in which they are involved i.e. the objectification of the subject and the subjectification (domination, control) of the object. ${ }^{4}$ This then allows them to be effectively studied genealogically so as to ascertain an explanation of the relations between discourse and society. Overall, Foucault finds the modern individual is the effect and object of the complex strategic developments in the field of power crossing multiple developments in the human sciences (Dreyfus \& Rabinow, p. 160). As a discourse, then, Islam would be viewed as a contributor to the power relations in society.

But a concern arises from his philosophical position rather than the treatment of discourse itself. Here it is important to recall some distinctions between types of truth, social and political subjects are often classed separately from the focus of the natural sciences. Foucault certainly blurred the distinction on a fundamental level with his above mentioned ideas of truth. But he gives no real credence to the truth of transcendental or revealed teaching, reading Nietzsche's attack against religion to spell the end of metaphysics (Foucault, 1999, p. 85). But one will not find Foucault actually explain the emergence of religion in secular terms, since as Schuld notes, Foucault's research constitute only partial social descriptions that remain empirical and set aside "all-encompassing interpretations" (Schuld, 2003, pp. 17-19). Nevertheless, Carrette writes that Foucault's thought by no means provides material for a theological understanding of the world (2000, p. x-xi, 1). Indeed, Foucault's main interest in religion appears to have been in its political and concrete dimensions, as first evinced in his 1978 treatment of the Iranian revolution (Carrette, 2000, p. 136).

A second sense in which there exists conflict is in the morally limited role Foucault assigns for religion. As noted above, Marx viewed religion as an instrument of class control yet he does maintain a moral aspect to his philosophy which at least parallels in broad terms religious doctrine. Marx's eschatology envisions the end of history in the resolution of the social contradictions in capitalist society. But Foucault has no such idea of social or moral "progression" where there is a final end with all contradictions resolved in complete political unity. Either way, power and knowl- 
edge are considered two sides of the same coin. "On the one hand, all knowledge is the effect of a specific regime of power, and, on the other hand, forms of knowledge constitute the social reality which they describe and analyse" (Foucault, 1977a, p. 27). Power both produces and sustains the procedures for discourse, its determination, its legitimisation, and its evocation by those sanctioned to speak on its behalf. With Foucault, the tools of investigation are not so much concerned with what discourse is saying, whether it is true or even comprehensible, rather the concern is with what role established discourses have played. This is because truth is measured in terms of power as they effect societal and political relations. As Hawkes points out, it is no longer possible to use terms such as "true", "false", in any absolute sense. Discourses give rise to "truth-effects" only, nothing that has any objectively veridical character. Therefore, for Foucault, it is not ideology that holds sway over us, but rather regimes of truth and the truth itself (Hawkes, 2003, p. 153).

This epistemological "neutrality" behind the genealogical method has both an advantage and a disadvantage. In the first instance, it appears there will arise no clash with Islamic creed precisely because discourse brackets grand narratives and truth claims from the beginning. In the second instance, however, the method assumes theoretical foundations that are opposed to religious belief. The bracketing of grand truth claims is the result of seeing truth as fundamentally historical and political. Thus the problem we found with Marx is also found with Foucault, for the goal of the Islamic sciences has an entirely different reference and that is to communicate and explain God's will for humanity along with the religious duties each individual believer has and that the Muslim community has as a whole. It would therefore be extremely difficult to find in them the same kind of secularly sourced political significance. This much is obvious enough, but that is not to say that the Islamic sciences have no contents formative of specific types of bio-power relations. Rather, questions arise about how divine truth can be conceived of along these lines or independently parallel to this theoretical framework. In Islamic belief, the fundamental truth must remain radically independent from worldly determination. For truth is found in revelation (See Tahawi, 2007, pp. 52-55) . Of course, once that truth arrives it can and will have implications amenable to treatment by the concepts of discourse and ideology, but the problem is with how discourse encompasses and conceives of revealed truth, more specifically, it assumes religious knowledge among the worldly determinations of power.

Happily, both concepts are separable from the religious uncertainty associated with them, a separation which is essential in light of Islamic belief in a transcendent God. Ideology is often interpreted simply as the doctrine that is fundamental 
to the action and outlook of a particular group, without there being any religious scepticism. As such it can be used in a fashion to characterise the social or political aspects of Muslim thought. Indeed, in Islamic intellectual endeavour, rather than simply a class conflict, there is such a normative struggle wrapped up in a different debate, most prominently the relationship of Islamic society and religion to the West and modernity in general. This can be seen in the writings, for example, of political theoretician Abdallah Laroui, in his analysis of different responses in Arab thought to Western advancement (1982, pp. 144-148), and Nagels treatment of the ideas centred around the belief that all useful knowledge that arrives from foreign lands is but part of the original teachings of God and His prophet (2000, pp. 256-260). In this sense, the term faithfully describes the thought of political activist Sayyid Jamal al-Din al-Afghani, in articulation of Islamic solidarity (Keddie, 1983, p. 35), modernist thinker Muhammad Abduh, in his desire to amend Islamic thought for modern times (Abduh, 2009) and nationalism in muslim lands generally, including the thought of figures such Hasan al-Banna (Karpat, 1982).

As for discourse, we mentioned earlier the prominent place in Islam of fiqh, which is more relevant to the order and structure of society and individuals. Fiqh is both communal and individual and so study of Islamic society must be orientated accordingly. The commands and prohibitions articulated in Islamic teaching hold believers in relations to one another as well as in a personal relation directly to God. The concept of discourse can serve to explain the relations of power that fiqh brings to society, and hence, properly study an Islamic society. In this context, it is easy to see what material a genealogist investigating an Islamic society will work with and such work has been carried out for example by Talal Asad (1993) and Wael Hallaq, who determines that the "technologies of the self" established by Islamic governance produces subjectivities antithetical to those produced by the modern state (2013, Chapter 5).

Specifically, Foucault, studies power by focusing upon the body in order to study "an endless play of dominations". As Shilling states, the body "constitutes the link between daily practices on the one hand and the large scale organisation of power on the other" (2003, p. 75). To see how power works Foucault identifies specific sites where these rituals take place and from there to see from where they emerged, took shape, gained importance and so on (Dreyfus \& Rabinow, 1983, p. 119). ${ }^{5}$ Such an investigation in an Islamic society would explain how the religious 
rituals that make a society Muslim and make the Muslim part of society in terms of the power relations that they express. The classical fiqh texts, express the foundations of a din, "a complete way of life". It is inhabited by numerous practices and rituals that impose rights and obligations. Foucault took great interest in these elements of life as phenomena that order and direct our lives. The term he used to describe an aspect of their significance was "bio-power", a form of domination, making the body useful by providing productive and subjected people. Bio-power reveals the connection between the large scale organisation of power and daily practices. The concept of discourse can be used to study such a relation.

Conceived in this way, the study of power is suited to take as its subject religious rituals such as those that form central parts of Islamic practice, including purification (tahaarah), prayer (salaah), charity (zakaah), and fasting (sawm). But here, there is no state or class imposition over the individual as one would suppose with and be limited to with ideology; worship does not count as part of modern law; this law is not determined by the state. Yet though studying power by focusing upon the body, Foucault's approach will reveal how these religious themes are socially important. They are also practices of spiritual rather than practical benefit. Taking the subject of taharah, for example, it is clear that the purity described here is not one of simply hygienic significance. With salah, the movement of the body is not merely for the purpose of physical exercise. In the case of sawm, the dietary commands are not simply a matter of nutritional and digestive health. They, as acts of worship in Islam, acquire a transcendental value and meaning. Qurbani, or udhiyyah, is a practice that brings the believer closer to God, as well as helping maintain social bonds and aiding the poor. And just as acts of worship possess practical benefits, in Islam acts of everyday life can gain the religious value. When a Muslim washes their hands three times, before sitting down to eat, with the intention of following the sunnah of the Prophet, they therefore receive sawab, divine reward in the dunya and akhira.

Hence, the transcendent and worldly are intermingled within the Islamic worldview and the large scale organization of power is of metaphysical rather than worldly character. And the "subjected" people are the mukallifeen. Just like worship is in Islam, bio-power is diffuse, and it is by looking at the body that Foucault can

tifies the all-encompassing organisation of society today as bio-power, itself the result of a complex strategy construct that increasingly captures everyone in its intent on increasing power and order. Interestingly, Dreyfus and Rabinow note that despite the meticulous attention to empirical detail required by genealogy (history found in ignoble archives), the diagnosis is only interpretive since it is not in any way empirically demonstrable (1983, pp. 122-125). 
study how this social regulation takes effect. God, as the ultimate Determiner of order, represents a heavenly and positive force the outward forms of which the genealogist is in a specific way apt to investigate. Similarly, the various practices of Islamic faith, as articulated by figh, keep the Muslim in awareness of their Lord and their submission to Him. And by this means, the domination of divine decree in the Muslims life competes, to some degree, with those of the state, society, science, culture and thus prevents the Muslim from falling into un-Islamic modes of life. Hallaq (2013) discusses this predicament in a wider context of the "paradigm" of Islamic governance and the alleged possibility of the Islamic state.

We have already noted the greater prominence and substance in Islam of law over creed, however more fundamental the later may be. In this situation the intricacy of the genealogical approaches can help reveal features of Islam as a lived religion, forming identities. What is more, in the genealogical approach the truth claims stemming from the society being studied are not judged, and this will again leave the validity of Islam entirely to one side. The genealogist views power relations not in terms of ruler and ruled. Rather, power constitutes a "complex strategical situation", as a "multiplicity of force relations" (Foucault, 1990, pp. 92-97). Domination occurs within what is described as a battle that is fixed in rituals and meticulous procedures that impose rights and obligations, making the body useful by providing productive and subjected bodies (Foucault, 1977b, p. 150). Some power relations may be a genuine part of the law; others may be simply contingent additions or manipulations. According to the Foucauldian approach, any normative evaluation of these additions is, strictly speaking, not really the genealogist's concern, but the distinction itself can be, and, indeed, normative evaluations can easily be added.

But it is essential to remember that discourse studies the power relations within society as instilled by science, knowledge, and culture in addition to political formations. In Islam the power relations are always going to be determined by God, for this is the whole purpose of Islamic jurisprudence and the principles of jurisprudence. God remains the determiner of society in this sense. This of course is not a total determination, the sphere of God's law extends as far as what He has commanded, and identifying the borders of this sphere is something the scholars of the sciences of jurisprudence have attempted to carry out (For one prominent modern example, see, Buti, 1966). This is significant because we are admitting the existence of a realm of truth whose contents are not determined simply or fundamentally by human thought and secular relations of interaction.

And such debates do not fall under what may be termed ideology, but rather science. Ideas of truth differed. The jurist generally fell into two groups. On the 
one hand there were those that believed God had not determined any particular judgement as true, and that therefore all scholars endeavouring to seek a valid judgement were correct, on the other hand, were those that held God had determined which judgment was true and that therefore only one opinion was right (See, Ayengin, 2005). Conservative tendencies naturally existed among the ulama. Al-Shafi's famous al-Risalah fi Usul al-Fiqh, which for the first time presented in a systematized way the sources of law, subordinated the more philosophical legal practices of istishan (to deem good) and istislah (to deem proper), which Faruki notes had the possibility of taking priority over the Quran and sunna (1994, p. 25). The idea essential to Islamic scholarship is that there is a truth which humanity is trying to access. But the degree to which this is achieved is recognised as variable. Abu al-Barakat al-Nasafi expresses well the general acknowledgment of the validity to the variation in interpretation: "When we are asked about our opinion and the opinions of our dissenters in the ancillary matters, it is obligatory for us to state that our opinion is correct, with the possibility of being an error, and the opinion of those who differ with us is an error, with the possibility of being correct" (as in al-Hanafi, 1999, p. 330). Of course, both Marx and Foucault deemed science as complicit with and a result of social formations, with ideological functions. And there is the question of what we can call science and what ideology, so well highlighted by our two thinkers. Indeed, the emergence of thinkers criticising the ulama for their ineffective responses to the example of the West resulted from the perceived failure to redress the difficulties that the Muslim world was facing due to the intellectual conservativism. As Koşum (2006) explains, it was indeed incumbent on the jurists to recognise the contribution of their subjectivity and the effect of history on the judgements that they make and for this reason to not describe their opinions with the term "objective" but rather "legitimate". And thus modernists like al-Afghani and Muhammad Abduh, cited above, raised a meta-criticism of Islamic scholarship, something that struck at the spirit, method and principles of fiqh and kalam present at that time, claiming the contents themselves therefore legitimately open to revision. In terms of law, this meant a division between those who held fiqh as the blueprint for society and those that saw it being shaped by society (Waines, 2003, p. 232).

The cogency of the Modernist critics does not simply stem from the conservative nature of the way the science was practiced but something more philosophical. Postmodernists often point out that the meaning a thing possesses is not intrinsic to it. There is always interpretation by the application of a context to the thing in question. Due to its concern with a true and normative arrangement of society, ideology does have a basic similarity with Islamic religious thought. Certainly, Is- 
lam itself is not an ideology, but social and political concerns inherently occupy and intervene on the social side of the Islamic sciences. This applies to the methods and principles of fiqh themselves, and questions about how to preserve Gods message. Fazlur Rahman surveys the various ways that the developments of nationalism, political-economics, and technology mean that education in Muslim countries "has to be more effectively integrated with basic cultural values" (2002, pp. 89-90).

Of course, neither Marx nor Foucault had to contend with remaining faithful to a particular divine message in making their theories. Therefore, Islamic belief requires a more complicated conception of how truth, especially truth in regards to the social order, is established. Yet it must be remembered both viewed their own work as authoritative, and in the case of Marx, even scientific. One basic problem that both Marx and Foucault faced to differing degrees of success is the application of their concepts to their own theories. The problem, as Eastman puts it in reference to Marx is: "how there can be an objective science of social evolution when scientific ideas are themselves so potent a force in determining its course." He explains that Marx conceived of reaching more objective truth by moving closer to "the consummation of the whole" process of reality's improvement (Eastman, 1935). According to Holloway, the essence of science is to see past fetishised appearances (See Holloway, 2002). Indeed, we may recall also the third definition of ideology too, where Marx broadens the concept of ideology to include the truthful class consciences and will of the proletariat. Exactly what epistemology arises from this is debated (See, Morrice, 1996, pp. 42-46; Parekh, 2015, Chapter 7; Lukács, 2013, Chapter 4), but the bottom line is that he had to forge some place for objectivity.

Whether Foucault was less successful as the authority of his theory is called into question. He seems to want to reserve some objective sphere of truth for his theories and approach, but there is an inherent problem with the reduction of truth to strategic societal structures itself. As White points out, where does the authority of Foucault's own discourse lie (1979, p. 114). How can we accept what the genealogist tells us when ideology is equated with science, truth, and knowledge? Genealogy attempts to move beyond totalising and essentialist theories that ideologies often advocate to replace them with a method of studying society that does not presume the existence of some anterior determining realm. But this leaves no room for Foucault's studies to have independent validity.

Hence, the two thinkers suffer, for if Marx finds space for objective truth, then religion may also arguably claim that space, and if, as with Foucault, there is no such truth, then the conception of religion as discourse and the various finding that result themselves become suspect. There is here, however, the interesting theolog- 
ical question of whether divine power determines truth, but we would first have to accept the metaphysical implications of the existence of God to allow this debate to occur. We may here recall the distinction between those aspects of Islam, especially fiqh, that are recognised as the product of human intellection. However, the subsumption of Islam itself and, indeed, Abrahamic religion in general, under either concept as it stands, is problematic. This is because a divide exists between the essential theological and epistemology doctrine of Islam and the political and social theories that are advanced within Islamic scholarship. For a Muslim then to maintain this division it is necessary to make metaphysical and historical assertions, but the proof for the existence of God lies in the knowledge of Him, and so falls back to epistemology again. This takes us back to the introduction of positive sciences in Europe and move away from religious and hence metaphysical doctrine, to the discrediting of revelation, and the historical contingency of this event in the West.

\section{The Nature of the Human Subject}

A second problem with the concepts of ideology and discourse are the associated views of the human subject. In Islamic thought the human is created in accordance to a specific "disposition", or "primordial human nature" (fitrah), which is regarded among Muslim scholars as contributory to correct faith, religion and legal and moral responsibility (see The Quran, 30:29, 95:4; see Hallaq, 1991; 'Abd al-Qadir, 1410, pp. 132-48; see also Coward, 2008, Chapter 5). It is the truth of the human subject that revelation was aimed at and to which it contents read. Accordingly, the truth of revelation also confirms a stable truth in the human being too, which connects the human to Gods message, and makes humanity's acting in certain ways correct. Otherwise the message would be completely arbitrary. The founder of one of the main Sunni orthodox schools of theology, al-Maturidi, states that the human was created as a microcosm of the universe, with divergent inclinations and contrary natural qualities; and various needs and desires for which He provided the means of fulfilling and a moral basis for peace and prosperity in revealed knowledge was provided to teach them on how to live rather than leave them alone face to face with their ignorance and heavy burden of needs (Al-Maturidi, 2010, pp. 67-68). Indeed, it is against wisdom to bring something into existence only to destroy it again; and that God therefore sent prophets with the knowledge that humanity needed to survive and prosper (Al-Maturidi, 2010, p. 167).

Marx's concept of the human being is complicated. On the one hand, he refers to the "species-being" of the human being, and on the other hand, criticizes the given concept of human nature to argue that it merely describes the totality of 
social relations. In the "Theses on Feuerbach", he complains that Feuerbach had to "abstract from the historical process and to define the religious sentiment regarded by itself, and to presuppose and abstract - isolated - individual", rather than critically examine this essence. For Marx, "the 'religious sentiment' is itself a social product," and the essence of the human is in reality but "the ensemble of social relations" (Marx \& Engels, 1976, pp. 570-571). Marx's position on human nature is a subject of criticism and debated (See, for example, Geras, 1983; Callinicos, 1989, esp, chapter 5), and there is little reason to theologically deny the importance of social relations to human beings, but to reduce the position merely to those relations would be reductionistic.

One thing, however, of which Foucault complains, is that the concept of ideology presupposes "a human subject on the line provided by classical philosophy, endowed with a consciousness which power is then thought to seize on" (1980a, p. 58). For Foucault, even "The universals of our humanism are revealed as the result of the contingent emergence of imposed interpretations." Indeed, "Nothing in man - not even his body - is sufficiently stable to serve as the basis for self-recognition or for understanding other men" (Foucault, 1977b, p. 153). Thus, "One has to dispense with the constituent subject, to get rid of the subject itself, that's to say, to arrive at an analysis which can account for the constitution of the subject within a historical relationship" (Foucault, 1980c, p. 117). It is in this way that Foucault's approach refuses to study the individual qua individual. Each person is but a part of a larger system that is not investigated as the product of any individual, rather the web of social meanings and power relations that these meanings constitute are studied as entities that transcend the individual. In "Questions on Geography," Foucault writes: "It's my hypothesis that the individual is not a pre-given entity which is seized on by the exercise of power. The individual, with his identity and characteristics, is the product of a relation of power exercised over bodies, multiplicities, movements, desires, forces" (Foucault, 1980b, p. 73).

Ultimately, it is the humanist notion of the subject as entirely unified, conscious, coherent and autonomous, which sits in relation to ideas of underlying laws and metaphysical finalities, that Foucault rejects. As Hawkes claims, when we interpret the flux of events into a coherent narrative, we are in fact imposing upon it our conception of our own subjectivity (2003, p. 154). Both Hegel and Marx, for example, conceived of history as heading towards some sort of completion that would end with the return of the original truth. In contrast, Foucault seeks to escape the teleological, totalising, subject-centred notions, which have dominated Western philosophy since Plato. He switches the direction of the re- 
lationship so that discourse establishes the human being, creating our sense of identity and form of life. Thus, Foucault assumes from the outset a rather un-Islamic conception of the human being. He follows Nietzsche; there is no subject, no "doer", "the doing is everything" (Nietzsche, 1998, p. 25). Yet, because Foucault follows Nietzsche, who held that such interpretations as those quoted above derive from "lowly origins" or the play of wills that comprise subjection, domination, and combat (Nietzsche, 1990, p. 288), Habermas finds Foucault implicitly derives his concept of power from the theory of the will to truth (2007, p. 287). Thus, an idea of what the basic human individual is must be presupposed among the ingredients behind Foucault's general framework of interpretation. That is to say, these "lowly origins" exist before discourse has been formed and done its work, or at least finds expression simultaneously with it.

The problems with a general dismissal of a human essence or soul independent of social relations can be seen in the work of Marxist philosopher Louis Althusser as an example of where both Marx and Foucault go wrong. In his celebrated essay, "Ideology and Ideological Sate Apparatuses," Althusser describes ideology as embodied in material practice, conveyed by the ideological state apparatus as opposed to the repressive state apparatus which functions by violence. Althusser adds, "The existence of ideas of [the subject's] beliefs is material in that his ideas are his material action inserted into material practices governed by material rituals which are themselves defined by the material ideological apparatus from which derive the ideas of the material subject" (Althusser, 1977, pp. 168-169). But as Hawkes says, "if ideas are material then the subject which has ideas must be an object." The subject enters into a world where ideology always already exists and so he or she must acquire their subjectivity with what ideological practices have made available (2003, p. 119), otherwise they will remain decentred thus unable to take any action due to an inability to bear reality (Eagleton, 1991, p. 141).

Here, the subject is "hailed" or "interpellated" into a pre-allocated subject-position by an ideological structure that works in the name of a centred Absolute Subject in a double mirror-connection. Ideology appears duplicated into an imaginary Subject and subjects. Eagleton argues that a problem with the notion of hailing is that it presupposes that the subject exists already in order to respond to its being hailed, as does the notion of identity based on self-reflection, since response, recognition, understanding are subjective faculties (1991, pp. 143-144). The problem is not unavoidable; Žižek argues that ideology is a necessary and given part of social reality (2008, pp. 24-25, 45). He writes, the 'subject is already present before subjectivation and recognition' (2008, p. 40). This is clearly an advancement over 
Althusser's theory, which suffers from an insufficient explanation of how a subject can be interpolated before they are a subject.

Althusser's presupposition corresponds to a problem with Foucault's account of the subject, that is, there is no subject without discourse. Shilling points out that whilst Foucault is concerned with the body as a material product of discourse that is constantly open to change and highly malleable, irrespective of time or place the body is always already equally available to external forces. This view is unable to consider that different aspects of human embodiment may be more or less open to discursive reconstruction (Shilling,1993, p. 80). This has implications for Foucault's account of resistance. As Dews notes, if we identify the body as no more than a corporeal tabula rasa there is little sense of how the body reacts against discourse (2007, p. 163). Norris writes that in Foucault's perspective, "the subject is little more than a 'place-filler, a recipient of moral directives which issue from some other, heteronomous source of authority, and which cannot be conceived as in any way belonging to a project of autonomous self-creation" (1994, p. 59). Foucault's last works, however, show how he eventually took into account the subject as an agent capable of a certain type of freedom. McNay writes this change allowed Foucault "to theoretically sustain the insight that the very means through which subjects are constrained may also constitute the means through which they may creatively express themselves" (1996, p. 106; see also Dews, 1989, p. 40). Thus, in his last works, Foucault shifts to a positive evaluation of the individual, which overcomes this weakness in his theory, and also thereby comes closer to traditional conceptions of the self.

\section{Conclusion}

The initial concern that we find with both Marx and Foucault's respective concepts of ideology and discourse is the theological scepticism that stands behind them, as neither makes space for the notion of genuine revealed or transcendent truth. We briefly traced this to the diminishing of scientific and intellectual authority of religion in Europe; something the Muslim world did not experience. With the concept of ideology the truth is directly connected to class interests and the history of society. Nevertheless, within this political context, ideology remains a concept that includes truth-apt descriptions of the social and political order, and maintains a space for genuine morality. Radically, discourse is uninterested in the truth of the statements it concerns, and rather with the truth-effects that they have. As we have seen, Marx views religion fundamentally as a tool of exploitation, and though Foucault does not target religion specifically, ideology and discourse are compa- 
rable because of their mutual reduction of truth claims to political and societal structures. But also we noted how this applies to their own writings, and though various commentators in addition to Marx himself sought to explain the objectivity of Marxism, Foucault appears generally unable to defend the authority of his work. On the one hand, therefore, we have an indication of truths that transcend social and political determination, making room for divine truth, and on the other, the need to properly demarcate legitimate bounds of this type of investigation, which we have suggested is already indicated by the distinction between the shariah and fiqh, where the latter is open to ideological criticism. Once this demarcation is made, the ideas of ideology and discourse can be utilised to explain how science, the social sciences especially, are collusive with power mechanisms.

In regards to the human subject, Marx's position is fairly ambiguous, while Foucault regards human identities as a product of social and political structures in their wielding of bio-power. Yet, with the development of the concept under Althusser and Žižek, for ideology there is the question regarding the constitution of the subject, which is resolved by the reintroduction of the human subject, if not a human essence. With the compelling post-modern critique of the autonomous, coherent subject, Foucault still had to adequately explain accounts of resistance and therefore also reintroduced some assumption of an independently constituted and pre-existing subject. In a basic sense, then, both concepts moved closer to the traditional Islamic notion of the self, as described under the term fitrah. Overall, the concept of discourse has clear potential to work in an agreeable way to Islamic fiqh and explain how power relations are constituted by the different branches of the law. It can do this exploring how religious practices make use of the body and how this constitutes actions that contribute to subjectivity and resistance. Yet, the key is to reject the dissolution of the subject, for this makes it thoroughly determined by discourse and prevents offering accounts for forms of knowledge other than those alive in discourse, such as subcultures and values and customs that originate in the past. What is more, we end up with a reductionist conception of power because of concentrating simply on its material effects. It is better, then, to simply consider Foucault's work as pointing to and opening up a specific area of research that when taken alone seems incomplete and even potentially inaccurate.

Though the intellectual trends that lead to the development and inclusion of the concepts of ideology and discourse in the study of society may be antithetical to Islamic doctrine, this fact does not make them useless to the study of Islamic society. Truth, power, knowledge, science, and the subject are all caught up in this issue. Marx's confrontation with the Hegelians shows that it is only by considering the material that we can have the ability to perceive change, to historicise 


\section{The Journal of Humanity and Society}

our knowledge and theories. Nevertheless, it is necessary for Muslim thinkers to identify and defend different terms and foundations for sociological investigation vis-à-vis those used in the West. In this light, groundwork that protects the notion of transcendent truth over and above ideologies and the concept of discourse, to make the latter two occupy a different category of truth, if not label them directly as representing mere illusions of truth. Essentially, given the differences observed, it appears necessary for a sociological science in harmony with Islamic belief to maintain central significance for the notion of individual in so far as it can act a moral anchor for the scope of interpretive analyses of society. This need is to an extent suggested by the limitations discovered in Foucault's approach as well as examples from Islamic scholarship and teaching.

\section{References}

'Abd al-Qadir, M. al-'Arusi. (1410). al-Masa'il al-mushtarak bayna usul al-fiqh wa-usual al-din. Jeddah.

Abduh, M. (2009). The theology of unity = Risālat al-tauhìd. Kuala Lumpur: Islamic Book Trust.

al-Hanafi, I. N. (1999). Al-Ashbah wal-Nazair (Vol. 1). Beirut: Dar al-Kotob al-Ilmiyya.

Al-Maturidi, A. M. (2010). Kitab al-Tawhid. (B. Topaloğlu \& M. Aruçi, Eds.). Beirut: Dar Sader.

Althusser, L. (1977). Lenin and philosophy and other essays (2. ed). London: New Left Book.

Asad, T. (1993). Genealogies of religion: discipline and reasons of power in Christianity and Islam. Baltimore: Johns Hopkins University Press.

Ashkar, U. S. (2002/1423). Tarikh al-fiqh al-İslâmî. Amman: Dâru al-Nefâis.

Ayengin, T. (2005). Hukûkî Dinamizm ve İçtihatta İsabet Tartışmaları. Marife 13(3), 139-158

Başdemir, H., Y. (2005). İskoç Aydınlanma Etiği: Hutcheson, Hume ve Smith. Liberal Düşünce, 37: 27-44.

Buti, M. S. R. (1966). Dawabit al-maslahah fi al-shari`ah al-Islamiyah. Dimashq: Matba`ah al-'Ilm.

Callinicos, A. (Ed.). (1989). Marxist theory. Oxford, England; New York: Oxford University Press.

Carrette, J. R. (2000). Foucault and religion: spiritual corporality and political spirituality. London ; New York: Routledge.

Collingwood, R. G. (1983). An essay on metaphysics. Lanham, MD: University Press of America.

Comte, A. (1853). The Positive Philosophy of Auguste Comte. (H. Martineau, Trans.). London: J. Chapman.

Coward, H. G. (2008). The Perfectibility of Human Nature in Eastern and Western Thought. Albany: State University of New York Press.

DeJean, J. (1997). Ancients Against Moderns: Culture Wars and the Making of a Fin de Siecle. Chicago: University of Chicago Press.

Dews, P. (1989). The Return of the Subject in Late Foucault. Radical Philosophy, 51, 37-41.

Dews, P. (2007). Logics of disintegration: post-structuralist thought and the claims of critical theory. London ; New York: Verso.

Dreyfus, H. L., \& Rabinow, P. (1983). Michel Foucault, Beyond Structualism and Hermeneutics (2nd ed.). Chicago: Univeristy of Chicago Press.

Eagleton, T. (1991). Ideology: An Introduction. London: Verso.

Eastman, M. (1935). Marxism: Science or Philosophy? New International. Retrieved from https://www.marxists.org/ archive/eastman/1935/science-philosophy.htm 
El Shamsy, A. (2008). The Social Construction of Orthodoxy. In The Cambridge Companion to Classical Islamic Theology. New York: Cambridge University Press.

Erdoğan, M. (2003). Fıkıh Usûlünün Katîliği. Bilimname : Düşünce Platformu, 1(2), 171-178.

Faruki, K. A. (1994). Islamic jurispurdence. Delhi: Adam Publishers \& Distributors.

Foucault, M. (1972). The Archeology of Knowledge. (A. M. Sheridan, Trans.). New York: Pantheon Books.

Foucault, M. (1977a). Discipline and Punish: The Birth of the Prison. (A. Sheridan M., Trans.). New York: Pantheon Books.

Foucault, M. (1977b). Nietzsche, Genealogy, History. In Language, Counter-Memory, Practice: Selected Essays. Ithaca, NY: Cornell Univ. Press.

Foucault, M. (1980a). Power/knowledge: selected interviews and other writings, 1972-1977. (C. Gordon, Ed.) (1st American ed). New York: Pantheon Books.

Foucault, M. (1980b). Questions on Geography. In Power and Knowledge: Selected Interviews and Other Writings, 1972-1977,. New York: Pantheon Books.

Foucault, M. (1980c). The Politics of Health in the Eighteenth Century. In C. Gordon (Ed.), Power/Knowledge: selected interviews and Other Writings, 1972-1977. New York: Pantheon Books.

Foucault, M. (1980d). Truth and Power. In Power/Knowledge: Selected Interviews and Other Writings, 1972-1977. New York: Pantheon Books.

Foucault, M. (1990). The History of Sexuality. Vol. 1: An Introduction (Reprint). London: Penguin Books.

Foucault, M. (1999). Philosophy and the Death of God. In J. Carrette (Ed.), Religion and Culture. New York: Routledge.

Foucault, M. (2002). The Order of Things: An Archaeology of the Human Sciences. London and New York: Routledge.

Geras, N. (1983). Marx and human nature: refutation of a legend. London: Verso.

Habermas, J. (2007). The Philosophical Discourse of Modernity: Twelve Lectures. (F. Lawrence, Trans.) (Reprinted). Cambridge: Polity Press.

Hallaq, W. B. (1991). Ibn Taymiyyah on the existence of God. Acta Orientalia, 52, 49-69.

Hallaq, W. B. (2013). The Impossible State: Islam, Politics, and Modernity's Moral Predicament. New York: Columbia University Press.

Hawkes, D. (2003). Ideology. London ; New York: Routledge.

Holloway, J. (2002). The Tradition of Scientific Marxism. In Change The World Without Taking Power. The Meaning of Revolution Today. Pluto Press. Retrieved from https://www.marxists.org/subject/marxmyths/john-holloway/ article.htm

Ibn Haldun. (2007). Mukaddime, I.Cilt. (S. Uludağ, Ed.). Istanbul: Dergah Yayınları.

Karpat, K. H. (Ed.). (1982). Political and social thought in the contemporary Middle East. New York, N.Y.: Praeger.

Keddie, N. R. (1983). An Islamic response to imperialism: political and religious writings of Sayyid Jamäl ad-Dīn "al-Afghānī." Berkeley: University of California Press.

Keller, A. C. (1950). Zilsel, the artisans, and the idea of progress in the Renaissance. Journal of the History of Ideas, 11(2). https://doi.org/https://doi.org/10.2307/2707248

Koşum, A. (2006). İçtihatta Hata ve İsabet Tartışmaları Işığında Öznellik ve Nesnellik Sorunu. Usul, 5(1), 5-32

Lacoste, Y. (2002). Tarih Biliminin Doğuşu: İbni Haldun. (M. Sert, Trans.). Istanbul: Don Kişot Corpus Yayınları.

Laroui, A. (1982). Contemporary Arab Ideology. In J. L. Donohue \& J. L. Esposito (Eds.), Islam in Transition. New York, Oxford: Oxford University Press.

Larrian, J. (1979). The Concept of Ideology. Hutchinson.

Lukács, G. (2013). History and class consciousness: studies in Marxist dialects. (R. Livingstone, Trans.). Cambridge, Mass: MIT Press.

MacNay, L. (1996). Foucault: a critical introduction (Reprinted). Cambridge: Polity Press. 


\section{The Journal of Humanity and Society}

Marx, K. (2009). Critique of Hegel’s “Philosophy of right.” (J. J. O’Malley, Ed.). Cambridge: Cambridge University Press.

Marx, K., \& Engels, F. (1976). The German Ideology: Including Theses on Feuerbach and Introduction to The Critique of Political Economy. New York: Prometheus Books.

Morrice, D. (1996). Philosophy, science and ideology in political thought. Basingstoke: Macmillan Press. Retrieved from http://site.ebrary.com/id/10613954

Nagel, T. (2000). The History of Islamic theology: From Muhammad to the Present. (T. Thorton, Trans.). Princeton, NJ: Markus Weiner Publishers.

Nietzsche, F. W. (1990). The Birth of Tragedy; and, The Genealogy of Morals. (F. Golffing, Trans.) (1st Anchor Books ed). New York: Anchor Books.

Nietzsche, F. W. (1998). On the Genealogy of Morality: a Polemic. (M. Clark \& A. J. Swensen, Trans.). Indianapolis, IN: Hackett Pub. Co.

Norgaard, R. B. (1994). Development Betrayed: The End of Progress and a Coevolutionary Revisioning of the Future. New York: Routledge.

Norris, C. (1994). Kant According to Foucault. In Reconstructing Foucault: Essays in the Wake of the 80s. Amsterdam: Rodopi.

Parekh, B. C. (2015). Marx's theory of ideology. London and New York: Routledge. Retrieved from http://public.eblib. com/choice/publicfullrecord.aspx?p=2028237

Pilling, G. (2009). Marx's “Capital”: Philosophy and Political Economy. London: Routledge.

Plamenatz, J. P. (1977). Man and society: a critical examination of some important social and political theories from Machiavelli to Marx. London: Longman.

Qardawi, Y. (1990). Madkhal li-Dirasat al-Shariat al-Islâmiyye. Cairo: Maktabah Wahba.

Rahman, F. (2002). Islam and modernity: transformation of an intellectual tradition (Repr). Chicago London: Univ. of Chicago Press.

Schuld, J. J. (2003). Foucault and Augustine: reconsidering power and love. Notre Dame, Ind: University of Notre Dame Press.

Shilling, C. (2003). The body and social theory (2nd ed). London: SAGE Publications.

Tahawi, A. I.-M. aț-. (2007). The Creed of Imam al-Tahawi: al-Aqìdah al-Ṭahāwiyyah. (H. Yusuf, Ed.) (First edition). Berkeley, California: Zaytuna Institute.

Waines, D. (2003). An introduction to Islam (2. ed). Cambridge: Cambridge University Press.

White, H. (1979). Michel Foucault. In Structuralism and Since: from Lévi Strauss to Derrida. Oxford: Oxford University Press.

Žižek, S. (2008). The Sublime Object of Ideology (Nachdr.). London: Verso. 